TABLE I.-Relative Impurity as Estimatea by Parmangana'e.

\begin{tabular}{|c|c|c|c|}
\hline & & 1 & \\
\hline $\left.\begin{array}{r}\text { Raw sewage deprived of } \\
\text { its suspended matter }\end{array}\right\}$ & $3 \cdot 696$ & & $\begin{array}{l}\text { Percentage purifica- } \\
\text { tion calculated on } \\
\text { clear raw sewage. }\end{array}$ \\
\hline 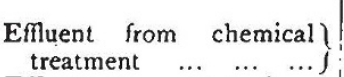 & 3.070 & & 16.9 \\
\hline $\begin{array}{l}\text { Effluent from single bac- } \\
\text { terial treatment } \ldots\end{array}$ & I.799 & & 513 \\
\hline $\begin{array}{c}\text { Effluent from double bac- } \\
\text { terial treatment } \\
\text { ? }\end{array}$ & $\mathrm{I} \cdot 137$ & & $69 \cdot 2$ \\
\hline $\begin{array}{c}\text { River water (high-tide) } \ldots \\
, ", \quad \text { (low'tide) } \ldots\end{array}$ & $\begin{array}{l}0.550 \\
0.429\end{array}$ & & 二 \\
\hline
\end{tabular}

(10) The bacteriological condition of the effluent corresponds in the main with that of the raw sewage. The total number of bacteria undergoes some reduction in the coke-beds, but the different kinds of bacteria which were present in the sewage are still represented in the effluent.

(II) The introduction of such a scwage ctiluent into the lower Thames is unobjectionalile. The river water at the points where the effluent is discharged is uniformly muddy; it is always brackish and frequently salt to taste, owing to the presence of tidal sea water. It is, therefore, not capable of being used for drinking purposes. The effluent would ccrtainly cause no deposit upon the river bed, and would ordinarily tend to render the muddy river water more clear by mixing with it. No offensive smell would be emitted by the effluent as it is dis. charged into the river. And, although the effluent contains more organic natter than the river water does, the bacteria which it contains would slowly and inoffensively remove this organic matter from the efluent after it has been introduced into the river. The effluent would be suitable for the maintenance of healthy fish.life.

\section{A PRE-COLUMBIAN SCANDINAVIAN COLONY IN MASSACHUSETTS.}

- $\mathrm{HE}$ evidence in favour of a partial settlement of Masca. chusetts by Scandinavians is gradually accumulating, and in the current number of the American Anthropo'osist (New Series, vol. ii., p. 550), Mr. Gerard Fowke adduces new observations. II says, few persons living among the evidences of Norse occupancy have ever paid any particular attention to them, taking for granted that they are the work of the earlier generations of English inhabitants of the region. Those who give more than a passing thought to these objects of unknown origin can see at cnce that many features connected with them not only would have been unsuitable for any of the necessities of the latter people, as they were then compelled to live, but could not have been turned to any practical use when completed. Such a conclusion is followed at once by the inference that they must pertain in some way to the social customs in vogue among the American Indians; but it does not require an extended acquaintance with aburiginal remains to convince an observer of the error of this inference, the two classes of works being entirely different in many of their most distinctive characters.

P'eculiar to the valley of the Charles river are the hut-sites excavated in the hillsides with their rows or piles of boulders to afford a resting place or foundation for the walls of the structures; the ditches that extend with practically a water level along the slopes of the hills; the dams that obstruct the river and many of its tributaries on both sides ; the artificial islands walled or protected with stones; the istone walls along the margin NO. I625, VOL. 63] of the streams, between high and low tide-none of these has a counterpart in any known works which can be attributed to Indian habits and life. Of very different character are the extensive earthworks in the bottom-lands; the hill-top fortifica. tions of earth and stone ; the immense fumuli of earth or stone, or both combined; and the huge flat-topped mounds of the Mississippi valley, erected by the Indian tribes popularly known as " mound-builders."

Remains of rectangular houses with very thick walls composed of stones and turf have been found of a size sufficient to accom. modate several families in the old Scandinavian fashion. The long-houses of the Iroquois and some of the larger houses built

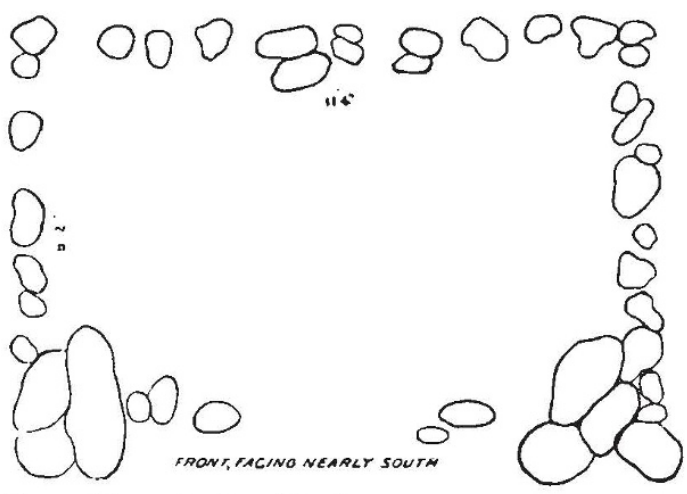

F1;. r. - House-site above Sibley's, on opposite side of swamp, near Massachusetts Central Railway.

by the Chippewa had the same general form, but with that the resemblance ceases. No foundation was necessary in the Indian house, and it was made principally or entirely of wood and bark. Similarly, nothing at all of Indian origin is known like the cot or hillside huts, of which a number have been examined. These are made by digging back into a sloping surface until a level floor of the desired area is formed ; sometimes stones were placed around the sides, in one case (Fig I) walls of stone and turf were built along the sides. There are indications that such places were ccvered with timber on which earth was piled.

Near Last Watertown is a large naturai depression or "kettle-

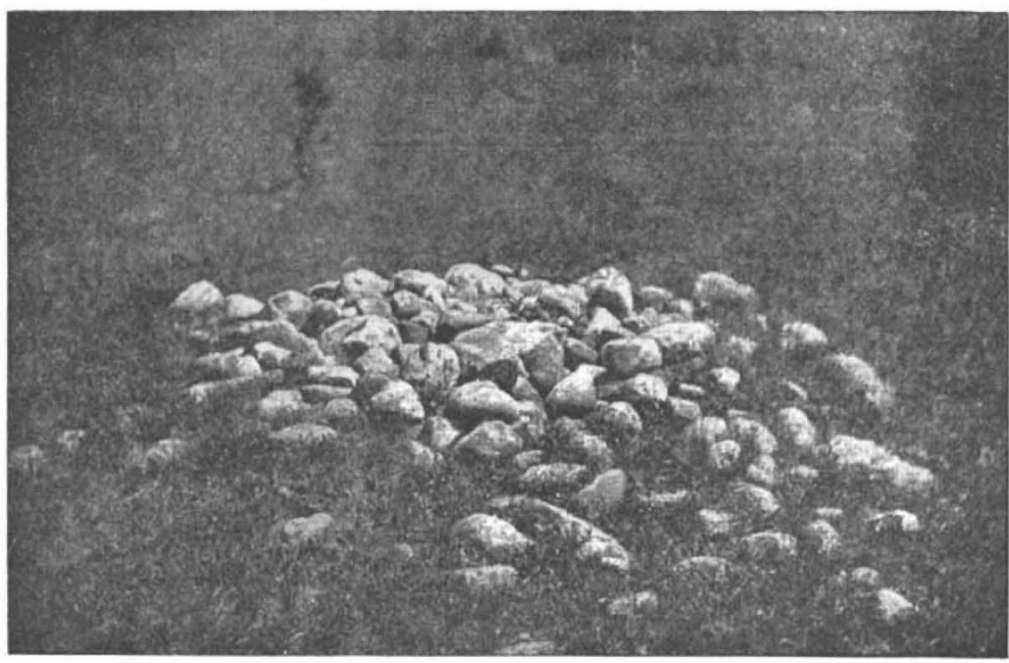

FIG. 2.-Supposed Norse grave at Clematis Brook, Charles River, Massachusetts.

hole." Around two-thirds of the circumference of this, artificial terraces have been constructed, apparently to furnish seats from which spectators might $v i \in w$ the exercises or ceremonies which presumably tonk place on the enclosed level asea at the toticm. Scneeutat more than a mile south of this" amphi. 
theatre," at one side of a small area of smuoth level bottom land, a sloping bank rises rather steeply to a height of perhaps thirty feet; along this slope are three or four terraces, not large enough to he of any use for tillage. There is nothing in the eastern part of the United States known to be of Indian origin with which these may be properly compared.

The author describes the various kinds of burial works of the Indians, and compares the numerous cairns found in Massachusetts with Indian stone mounds, but most of these were very much larger than any cairns supposed to be constructed by the Norse. The Indian graves contain skeletons and relics. The stone cairns, the cairns in question, are called graves because they answer, in every particular of size and situation, to those mentioned in different sagas, and are in the midst of various other remains which must be attributed to the Northmen; and yet, in all that have been examined there has not been found the slightest tracc of bone or any object which shows the least indication of being artificial. This, however, is only negative evidence; the same sta ${ }^{\prime}$ ement is true in regard to the graves of Iceland and Greenland; and not only of the graves in these countries, but also of the house-sites. It is also apparent that they differ from Indian graves even more in the manner of their interior construction tnan in their out ward appearance.

A. C. H.

\section{PROGRESS OF SCIENCE TEACHING.}

THE first report of the newly organised Board of Education has now been published. It consists of three volumesthe first contains the general report of the Board, the second is concerned only with secondary, and the third volume only with elementary education. A very important part of the second volume comprises the reports of the inspectors of the South Kensington branch of the Board of Education, who have charge of the teaching of science and art in different parts of the country. Without exception the inspectors tell a gratifying story of better equipment, improved methods, and saner ideals in the science schools visited by them. But though there has been a decided step forward there is still much to be accomplished and plenty of need for the best energies of both inspectors and teachers.

The reports are full of interesting details, it is truc, yet certain broad questions touched upon by nearly every inspector are likely to be of greater general interest. The first of these the senior chief inspector, Mr. Gilbert Redgrave, refers to at some length. Readers of NATURE are already quite familiar with itthe unsatisfactory condition, that is, of the preliminary education of science and technical students in all parts of the country. Mr. Redgrave says: "I find that in a very large number of cases the work of the teacher in an evening class under this Board is crippled and rendered ineffective owing to the backward state of many of the students who enter the classes, and who are really only qualified for the evening continuation school." As Dr. Ball points out, in his report on the work of the South-Western district, the science inspector has no connection with public elementary education and consequently no means of officially acquainting himself with what provision is made for the teach. ing of science in the elementary school, and there can be little doubt that it is this want of continuity which is very largely to blame for the disparity between what an ex-standard scholar actually knows and what he should be acquainted with if he is to benefit by the instruction of the science class or technical school. Fortunately, local endeavour is doing something to remedy this evil. Mr. Hugh Gordon tells of an arrangement in the county of Durham by which, during the year with which his report is concerned, the County Council refused to grant aid on the attendance of students at a class in a subject unless the students could produce satisfactory evidence to show they possessed the necessary preparatory knowledge, or would attend concurrently such other classes as the teacher considered desirable. Similar instances could be cited, but this example will serve to exemplify what attempts are being made to cope with a real danger to our system of national technical education.

Another subject which very properly takes an important place in most of the reports is the need of practical instruction in all science teaching. There has, the reports show, been a decided improvement in the amount and character of the practical work in all branches of science, except, perhaps, in the case of physiography. In order to enable teachers to illustrate their lessons with properly prepared experimental demonstrations, NO. I 625 , vOL. 63$]$ and to foster individual practical work for their students, they must be given time in which to prepare such lessons. We are glad to see that Mr. Harold Wager calls prominent attention to this fact in his report on the Y'orkshire division. He says: "The governors or managers of many of these schools have not yet fully appreciated the fact that teachers of practical science subjects require a considerable amount of time for the preparation of the experiments for their lessons beyond the time actually devoted to teaching. The necessary preparation for a good practical lesson in the laboratory is no light task, and if the work is to be done properly the teacher must have time for it."

Some progress in the direction of co-ordinating the work of the numerous local authorities for education has been made, but there still seems to be considerable misapprehension as to the precise limits of the sphere of influence of each committee or other governing body. It is gratifying to see that broad-minded counsels have prevailed in many centres, with the result that the very large amount of energy thereby saved has been devoted to the improvement of the local supply of scientific and technical instruction. Mr. Kedgrave sketches a plan by which the different schools may work together in a satisfactory and harmonious manner. "The Technical School under the Town Council should be a day school for students who have passed through a course of two or three years in a School of Science, which might be conducted by the School Board, and who may desire to qualify themselves for good positions in industrial or commercial pursuits. The School of Science managed by the School Board would in each case be the preparatory school for the Technical School, but it would also provicle an education complete in itself for those who leave school at the age of fifteen or sixteen. The evening classes at the Technical School should be classes in connection with the Board, or with the City and Guilds of London Institute, while the evening classes under the School Board should in all cases be those of the evening continuation school, and students should be encouraged to prepare for the classes under the Technical Instruction Committee by a course of study in the evening continuation school." Similar plans have, indeed, been alreacly tried with great advantage in several centres, and it is much to be desired that some sucb sensible system of co-operation should be universally adopted.

Only part of the science teaching given in secondary schools comes within the purview of the reports under consideration, that, namely, which takes place in secondary schools receiving financial aid from the Board of Education. Mr. Buckmaster deals almost exclusively with this part of the work of the South Kensington branch of the Board. Among other matters which his report makes clear is the fact that there is likely to be some difficulty in the future in those cases where the inspector of the Board of Education and the organising secretary of ${ }^{\circ}$ County Council Technical Instruction Committee come to different conclu. sions about a schoul after inspecting it. As Mr. Buckmaster says, "even in a county area cases may occur where the County Technical Committee will deprecate criticism on the schools is has selected as recipients of its grants."

The.points of interest in this very valuable volume have been by no means exhausted by this brief notice. The chief topics only have been pissed in review; the interested reader must be referred to the reports themselves for a more detailed account of a vitally important subject.

\section{UNIVERSITY ANID EDUCATIONAL INTELIIIGENCE.}

Dr. ARThur Robisson has been appointed professor of anatomy at King's College, London.

Science states that in an address to the students of Colorado College, Dr. D. K. Pearsons, of Chicaso, announced that on January i, 190I, he would make the college a gift of 10,000 $l$. towards the cost of completing the new scientific building now in course of construction.

A $\mathrm{T}$ the close of his rectorial address at Aberdeen University on Tuesday, Iord Strathcona expressed his willingness to contribute $25,000 \%$. to the University if within a year 50,000/. more were raised to complete the buldings and properly equip the University. Mr. Charles W. Mitchell has telegraphed to the Principal that he will be responsible for the whole of the present debt on the University buildings if it does not much exceed 20,000/. Mr. Mitchell is a son of the late Dr. Charles Mitchell, who was a liberal benefactor of the University. 